\title{
IMPLEMENTASI KEBIJAKAN PROFESI GURU MENURUT UNDANG-UNDANG REPUBLIK INDONESIA NOMOR 14 TAHUN 2005 TENTANG GURU DAN DOSEN DALAM PERSPEKTIF HUKUM PENDIDIKAN
}

\author{
oleh: \\ Cecep Darmawan
}

\begin{abstract}
ABSTRAK
Guru memiliki yang sangat strategis bagi kemajuan pendidikan suatu bangsa. Namun, pada tataran kebijakan dan implementasi profesi guru masih menyisakan berbagai persoalan baik menyangkut status guru sebagai profesi maupun kebijakan pendidikan profesi guru. Adanya Undang-Undang Republik Indonesia Nomor 14 Tahun 2005 tentang Guru dan Dosen atau UUGD menjadi landasan hukum bagi profesi guru. Hasil dalam penelitian ini yakni dalam UUGD terdapat ketentuan yang menegaskan profesi guru tidak lain merupakan profesi yang amat terbuka. Artinya setiap sarjana baik dari lulusan sarjana pendidikan maupun nonkependidikan pun memiliki kesempatan yang sama menjadi guru jika memenuhi persyaratan yang telah diamanatkan oleh UUGD, diantaranya yaitu memiliki kualifikasi akademik minimal S1 atau D-IV kependidikan maupun nonkependidikan, memiliki kompetensi yang diperoleh melalui pendidikan profesi guru serta memiliki sertifikat pendidik. Penyelenggaraan pendidikan profesi guru setelah berlakunya UUGD menggunakan model konsekutif (consecutive). Akan tetapi disisi lain juga masih mempertahankan model konkuren (concurrent) yang diselenggarakan pada perguruan tinggi LPTK.
\end{abstract}

Kata Kunci: Profesi Guru, Pendidikan Profesi Guru, Undang-Undang Guru dan Dosen.

\section{PENDAHULUAN}

Mencerdaskan kehidupan bangsa merupakan salah satu tujuan nasional yang terdapat dalam Pembukaan Undang-Undang Dasar Negara Republik Indonesia Tahun 1945. Tujuan tersebut menegaskan negara bertanggung jawab dalam penyelenggaraan pendidikan yang bermutu bagi seluruh warga negara. Pendidikan merupakan hak asasi yang mendasar bagi seluruh warga negara yang harus dipenuhi oleh negara. Persoalan Pendidikan diatur dalam Pasal 31 Undang-Undang Dasar Negara Republik Indonesia Tahun 1945.

Upaya mencapai tujuan nasional melalui pendidikan diimplementasikan dengan dibentuknya Undang-Undang Republik Indonesia Nomor 20 Tahun 2003 tentang Sistem Pendidikan Nasional. Undang-Undang ini yang menjadi landasan bagi terselenggaranya sistem pendidikan di Indonesia.

Pendidikan merupakan tanggung jawab dari setiap pemangku kepentingan (stakeholders) pendidikan, akan tetapi dalam praktiknya yang paling bertanggung jawab untuk mendidik peserta didik adalah guru. Peran guru sangatlah sentral bagi dunia pendidikan suatu bangsa. Untuk itu, guru harus dipandang sebagai profesi yang profesional dalam menjalankan tugasnya. Hal tersebut sejalan dengan pandangan Subijanto bahwa salah satu faktor esensial yang berpengaruh terhadap kualitas hasil pendidikan adalah guru. Sebagai pendidik profesional, guru memiliki peran yang strategis dalam pendidikan. Dengan diundangkannya Undang-Undang Republik Indonesia Nomor 14 Tahun 2005 tentang Guru dan Dosen (UUGD), guru diakui sebagai jabatan profesional. ${ }^{1)}$

Adanya Undang-Undang Republik Indonesia Nomor 14 Tahun 2005 tentang Guru dan Dosen yang dapat disingkat menjadi UUGD menjadi landasan hukum bagi profesi guru.

1) Subijanto, "Profesi Guru sebagai Profesi yang Menjanjikan Pasca Undang-Undang Guru dan Dosen", Jurnal Pendidikan dan Kebudayaan, Balitbang Kemendikbud, Jakarta, 2007, hlm. 696. 
Undang-Undang ini menegaskan bahwa guru merupakan suatu profesi yang dituntut profesional, sehingga tidak setiap orang dapat menjadi guru. Pasal 1 angka 1 Undang-Undang Republik Indonesia Nomor 14 Tahun 2005 menyebutkan bahwa guru adalah pendidik profesional dengan tugas utama mendidik, mengajar, membimbing, mengarahkan, melatih, menilai, dan mengevaluasi peserta didik pada pendidikan anak usia dini jalur pendidikan formal, pendidikan dasar, dan pendidikan menengah.

UUGD ini dalam implementasinya menimbulkan berbagai permasalahan yang begitu kompleks khususnya yang menyangkut mengenai persoalan kebijakan profesi guru. Faridah Alawiyah menyebutkan bahwa: ${ }^{2}$

"Permasalahan tersebut antara lain masih timpangnya ketersediaan guru antarlembaga pendidikan dan antarwilayah; program sertifikasi guru yang masih syarat dengan masalah (pelaksanaan program, pembiayaan); belum signifikannya dampak berbagai program peningkatan kualifikasi dan kompetensi guru terhadap peningkatan kualitas pembelajaran dan hasil belajar siswa; belum memadainya kapasitas LPTK, terutama LPTK swasta dalam menciptakan guru berkualitas; pengembangan serta jenjang karir guru yang masih belum jelas; upaya perlindungan terhadap guru masih rendah; kurangnya perhatian terhadap peningkatan kesejahteraan guru; adanya diskriminasi terhadap guru swasta dengan guru negeri, guru honorer dan guru PNS, serta UUGD yang sudah tidak relevan lagi dengan dinamika nasional."

Permasalahan-permasalahan di atas merupakan kondisi riil bahwa guru masih menyisakan berbagai persoalan serius yang harus ditangani oleh pemerintah secara komprehensif.

Diakuinya guru sebagai profesi yang profesional, membuat guru harus menempuh pendidikan profesi sebagaimana profesi lainnya yakni dokter, advokat atau pengacara, maupun notaris. Artinya, ketika seseorang menempuh S1 Kependidikan dan lulus dari Lembaga Pendidikan Tenaga Kependidikan (LPTK) serta mendapat gelar Sarjana Pendidikan (S.Pd.), ia belum dapat dikatakan sebagai seorang guru. Untuk memperoleh gelar profesi sebagai seorang guru ia harus menempuh Pendidikan Profesi Guru (PPG) terlebih dahulu. Dengan demikian, dapat dikatakan bahwa pendidikan akademik S1 Kependidikan dilakukan secara terpisah dengan pendidikan profesi guru. Perlu diketahui mengenai jenis pendidikan tinggi yakni pendidikan akademik, pendidikan profesi, dan pendidikan vokasi diatur dalam Undang-Undang Republik Indonesia Nomor 12 Tahun 2012 tentang Pendidikan Tinggi.

Adanya syarat yang mengharuskan seseorang yang lulus S1 Kependidikan harus mengikuti PPG merupakan konsekuensi logis dari adanya UUGD. Adanya UUGD membuat perguruan tinggi yang menjadi Lembaga Pendidikan Tenaga Kependidikan (LPTK) mulai dari Desember 2005, tidak memiki kewenangan untuk mengeluarkan Akta IV sebagai sertifikat bagi guru untuk dapat mengajar pada satuan pendidikan tertentu. Sebagai gantinya, seseorang yang telah lulus S1 Kependidikan dan mendapat gelar S.Pd. harus mengikuti PPG agar dapat diakui dan mendapat gelar sebagai guru yang profesional. Akan tetapi, yang perlu dicatat tidak seluruh LPTK dapat menyelenggarakan PPG, melainkan hanya perguruan tinggi LPTK yang memenuhi persyaratan sebagaimana diatur oleh peraturan perundang-undangan. ${ }^{3)}$

Undang-Undang Guru dan Dosen memuat ketentuan bahwa sejak diberlakukannya yakni pada Desember 2005, semestinya pemerintah harus memastikan selama sepuluh tahun sejak UUGD berlaku para guru di seluruh Indonesia sudah harus tersertifikasi. Artinya sesuai amanat UUGD, seharusnya pada Januari 2016 para guru di seluruh Indonesia sudah mengikuti

2) Faridah Alawiyah, "Problematika Tata Kelola Guru dalam Implementasi Undang-Undang Guru dan Dosen". Aspirasi: Jurnal Masalah-Masalah Sosial, Bidang Kesejahteraan Sosial Pusat Penelitian Badan Keahlian DPR RI, Jakarta, 2018, hlm. 119.

3) Cecep Darmawan, "Kontroversi Profesi Guru”, Harian Umum Pikiran Rakyat, PR, Bandung, 2018. 
sertifikasi guru. Akan tetapi, dalam kenyataannya masih banyak guru-guru yang belum tersertifikasi sampai dengan tahun 2020.

Perlu diketahui sejak adanya otonomi daerah, terdapat adanya pembagian urusan antara pemerintah pusat dan pemerintah daerah dalam bidang pendidikan. Hal tersebut sebagaimana tercantum dalam Pasal 12 Ayat (1) Undang-Undang Republik Indonesia Nomor 23 Tahun 2014 Tentang Pemerintahan Daerah bahwa salah satu urusan pemerintahan wajib yang berkaitan dengan pelayanan dasar adalah dalam bidang pendidikan. Otomatis dengan adanya ketentuan ini, membuat pengelolaan pendidikan termasuk pengangkatan guru menjadi kewenangan pemerintah daerah. Oleh karena itu, pemerintah daerah semestinya harus mematuhi amanat UUGD yang mewajibkan mengangkat guru PNS bagi mereka yang telah mengikuti PPG (memiliki sertifikat) sejak Januari 2016. Namun dalam realitanya, pada tahun 2020 pun masih ada upaya perekrutan guru yang belum tersertifikasi yang dilakukan oleh pemerintah daerah maupun sekolah. Adanya kekurangan guru akibat kebijakan moratorium PNS guru, sehingga pada sejumlah sekolah menjadi alasan dilakukannya perekrutan guru yang belum tersertifikasi oleh pemerintah daerah atau oleh pihak sekolah.

Berdasarkan latar belakang masalah sebagaimana diuraikan di atas, peneliti mengidentifikasi rumusan permasalahan utama yang akan menjadi fokus kajian dalam penelitian ini sebagai berikut:

1. Bagaimana implementasi kebijakan profesi guru dalam Undang-Undang Republik Indonesia Nomor 14 Tahun 2005 tentang Guru dan Dosen?

2. Bagaimana implementasi kebijakan pendidikan profesi guru dalam Undang-Undang Republik Indonesia Nomor 14 Tahun 2005 tentang Guru dan Dosen?

\section{TINJAUAN TEORITIS}

Konsepsi negara hukum Indonesia secara eksplisit tercantum dalam Pasal 1 Ayat (3) UUD NRI Tahun 1945 yang menyebutkan bahwa negara Indonesia adalah negara hukum. Negara Indonesia bukan negara atas dasar kekuasaan tetapi negara yang berasaskan hukum merupakan penegasan yang cukup jelas. Hukum menjadi landasan utama bagi penyelenggaraan kenegaraan. Nur Yanto menyebutkan bahwa asas negara hukum merupakan negara yang berdiri di atas hukum yang menjamin keadilan kepada warga negaranya. Asas negara hukum (rechtsstaat) cirinya yaitu 1) adanya Undang-Undang Dasar atau konstitusi yang memuat tentang hubungan antara penguasa dan rakyat, 2) adanya pembagian kekuasaan, dan 3) diakui dan dilindungi adanya hak-hak kebebasan rakyat. ${ }^{4)}$

Indonesia sendiri menganut konsepsi negara hukum dalam pengertian rechtsstaat yaitu negara yang memiliki karakteristik civil law berupa administrative. Terkait dengan keadilan bagi profesi guru, maka pemerintah sedapat mungkin mengupayakan sistem pendidikan guru yang berpihak terhadap model pendidikan guru yang menyatukan pendidikan akademik dengan pendidikan profesinya. Begitu pun sudah saatnya profesi guru harus dilindungi oleh peraturan perundang-undangan. Hal ini bertujuan agar guru tidak mendapatkan diskriminasi dalam menjalankan tugas dan kewajibannya dalam rangka mencerdaskan kehidupan bangsa. Guru semestinya mendapatkan persamaan di depan hukum serta mendapatkan keadilan hukum sebagaimana tujuan hukum itu sendiri.

Tujuan hukum dikemukakan oleh Jimly Asshiddiqie bahwa di kalangan para ahli hukum, pada umumnya dipahami bahwa hukum mempunyai tiga tujuan pokok, yaitu (i) keadilan (justice), (ii) kepastian (certainty atau zekerheid), dan (iii) kebergunaan (utility). Keadilan itu sepadan dengan keseimbangan (balance, mizan) dan kepatutan (equity), serta kewajaran (proportionality). Sedangkan, kepastian hukum terkait dengan ketertiban (order) dan

\footnotetext{
4) Nur Yanto, Pengantar Hukum Tata Negara Indonesia, Mitra Wacana Media, Jakarta, 2017, hlm. 68.
} 
ketenteraman. Sementara, kebergunaan diharapkan dapat menjamin bahwa semua nilai-nilai tersebut akan mewujudkan kedamaian hidup bersama. ${ }^{5)}$

Berdasarkan pandangan Jimly Asshiddiqie di atas, maka profesi guru sudah semestinya dilindungi secara hukum. Hal ini dikarenakan guru harus mendapatkan keadilan profesi serta mendapatkan kepastian hukum dalam menjalankan pekerjaannya, sehingga para guru dapat menjalankan kewajibannya dalam mencerdaskan kehidupan bangsa dan memajukan pendidikan di negara Indonesia.

Hukum tata negara merupakan bagian dari ilmu hukum yang begitu penting dalam penyelenggaraan kehidupan ketatanegaraan suatu negara. Yuswalina dan Kun Budianto menjelaskan bahwa letak pentingnya Hukum Tata Negara dalam kehidupan berbangsa dan bernegara adalah untuk memperlihatkan suasana ketatanegaraan, susunan pemerintahan, wewenang dan hubungan antara alat perlengkapan yang ada dalam suatu negara, untuk bekerja mencapai tujuannya baik dalam hubungan internal maupun dalam hubungan eksternal serta perlindungannya terhadap hak asasi manusia. ${ }^{6}$ Moh. Kusnardi dan Harmaily Ibrahim, dalam buku "Pengantar Hukum Tata Negara Indonesia", dinyatakan bahwa: Hukum Tata Negara dapat dirumuskan sebagai sekumpulan peraturan hukum yang mengatur organisasi dari pada negara, hubungan antar alat perlengkapan negara dalam garis vertikal dan horizontal, serta kedudukan warga negara dan hak azasinya. ${ }^{7)}$

Berdasarkan pandangan ahli tersebut, dalam konteks penelitian ini, peneliti mengartikan bahwa Hukum Tata Negara merupakan hukum yang mengatur bagaimana tugas, wewenang, dan kedudukan lembaga negara sebagai organisasi negara yang mengatur bagaimana lembaga negara bekerja dan bagaimana hubungan antaralat perlengkapan negara. Dalam kajian mengenai kebijakan pendidikan, lembaga negara yang memiliki kewenangan dan urusan pendidikan ialah pemerintah pusat dan pemerintah daerah.

Hukum pendidikan tidak lain adalah hukum yang berkenaan dengan hal ikhwal atau seluruh aspek pendidikan yang berkaitan dengan sistem pendidikan nasional. Konsepsi Hukum Pendidikan tidak lepas dari hukum tata negara sebagaimana dijelaskan di atas. Pembukaan UUD NRI Tahun 1945 telah mengamanatkan tujuan bernegara diantaranya mencerdaskan kehidupan bangsa. Artinya negara memiliki kewajiban yang asasi dalam hal mencerdaskan rakyatnya. Amanat Pembukaan UUD NRI Tahun 1945 ini diperkuat oleh Pasal 31 UUD NRI Tahun 1945.

Urusan atau kewenangan pendidikan merupakan urusan pemerintahan yang konkuren. Dalam Pasal 9 Ayat (3) Undang-Undang Republik Indonesia Nomor 23 Tahun 2014 Tentang Pemerintahan Daerah disebutkan bahwa yang dimaksud dengan urusan pemerintahan konkuren adalah urusan pemerintahan yang dibagi antara pemerintah pusat, daerah provinsi, dan daerah kabupaten/kota.

Pendidikan merupakan salah satu urusan yang bersifat layanan dasar wajib bagi warga negara di daerah. Artinya penyelenggaraan pendidikan wajib dilakukan oleh pemerintah baik pemerintah pusat maupun daerah provinsi dan kabupaten/kota. Hal ini sebagaimana disebutkan dalam Pasal 12 Ayat (1) Undang-Undang Pemerintahan Daerah bahwa salah satu urusan pemerintahan wajib yang berkaitan dengan pelayanan dasar ialah pendidikan.

Pemerintah sendiri telah membuat kebijakan mengenai standar nasional pendidikan yang terdiri dari delapan standar sebagaimana diatur dalam Pasal 1 Peraturan Pemerintah Republik Indonesia Nomor 13 Tahun 2015 tentang Perubahan Kedua Atas Peraturan Pemerintah Nomor 19 Tahun 2005 tentang Standar Nasional Pendidikan, diantaranya yaitu a) Standar Kompetensi Lulusan, b) Standar Isi, c) Standar Proses, d) Standar Pendidik dan Tenaga Kependidikan, e)

5) Jimly Asshiddiqie, Pengantar Ilmu Hukum Tata Negara Jilid I, Sekretariat Jenderal dan Kepaniteraan MK RI, Jakarta, 2006, hlm. 149.

6) Yuswalina dan Kun Budianto, Hukum Tata Negara Indonesia, Setara Press, Malang, 2016, hlm. 1.

7) Jimly Asshiddiqie, Op.cit, hlm. 33. 
Standar Sarana dan Prasarana, f) Standar Pengelolaan, g) Standar Pembiayaan Pendidikan, dan h) Standar Penilaian Pendidikan.

Kajian dalam penelitian ini ialah berkenaan dengan standar pendidik dan tenaga kependidikan khususnya mengenai profesi guru. Peneliti tertarik mengkaji permasalahan kebijakan profesi guru dalam perspektif hukum pendidikan dikarenakan dalam implementasinya banyak ketidakadilan terhadap profesi guru. Profesi guru mengalami diskriminasi dibandingkan profesi lainnya seperti profesi advokat maupun dokter. Diskriminatif profesi tersebut terdapat dari kebijakan profesi guru itu sendiri yakni dalam Undang-Undang Republik Indonesia Nomor 14 Tahun 2005 tentang Guru dan Dosen maupun dalam implementasi UUGD tersebut. Dengan demikian, peneliti bermaksud untuk mengkaji berbagai kebijakan mengenai profesi guru dalam perspektif hukum pendidikan.

\section{PEMBAHASAN}

Kebijakan profesi guru di Indonesia diatur dalam Undang-Undang Republik Indonesia Nomor 14 Tahun 2005 tentang Guru dan Dosen (selanjutnya disebut UUGD). Undang-undang ini mengatur mengenai konsep-konsep, prinsip-prinsip dan ketentuan yang berkaitan dengan guru yang merupakan salah satu bagian dari kebijakan dalam bidang pendidikan. Untuk itu, adanya Undang-Undang Guru dan Dosen merupakan salah satu dasar hukum yang menjadi kajian dalam hukum pendidikan.

Sejak adanya Undang-Undang Guru dan Dosen, guru diakui sebagai tenaga pendidik profesional. Adapun tugas utama guru berdasarkan UUGD diantaranya yaitu mendidik, mengajar, membimbing, mengarahkan, melatih, menilai, dan mengevaluasi peserta didik. Tugas utama guru tersebut dijalankan pada pendidikan anak usia dini jalur pendidikan formal, pendidikan dasar, dan pendidikan menengah.

Guru yang profesional tentunya harus memenuhi prinsip-prinsip atau ciri-ciri dari pekerjaan seorang profesional. Dalam UUGD, yang dimaksud dengan profesional adalah pekerjaan atau kegiatan yang memiliki prinsip-prinsip profesionalitas sebagai berikut 1) menjadi sumber penghasilan kehidupan, 2) memerlukan keahlian, 3) memerlukan kemahiran, 4) memerlukan kecakapan, 5) memenuhi standar mutu atau norma tertentu, dan 6) memerlukan pendidikan profesi.

Dalam ketentuan UUGD, guru memiliki kedudukan sebagai tenaga pendidik yang profesional dalam suatu jenjang dan jalur pendidikan tertentu. Guru berhak diangkat sebagai tenaga pendidik yang profesional dalam jenjang dan jalur pendidikan tertentu. Adapun syarat untuk dapat memiliki kedudukan dan diangkat dalam jenjang dan jalur pendidikan yakni dibuktikan dengan adanya sertifikat pendidik. Untuk itu, pasal ini yang menjadi dasar hukum bagi adanya proses sertifikasi guru melalui pendidikan profesi guru.

Kedudukan guru sebagai tenaga profesional merupakan bentuk pengembangan profesi guru. Adanya UUGD merupakan bentuk pengakuan bahwa guru merupakan sebuah profesi yang profesional. Adapun fungsi dan tujuan dari diangkatnya guru sebagai tenaga profesional dalam kedudukan tertentu dalam suatu jenjang dan jalur pendidikan. Pengakuan guru sebagai tenaga profesional sebagaimana dinyatakan dalam UUGD berfungsi diantaranya yaitu a) untuk meningkatkan harkat dan martabat guru, b) untuk meningkatkan peran dan marwah guru sebagai agen-agen pendidikan, dan c) untuk menjamin peningkatan mutu pendidikan nasional.

Tujuan dari diakuinya kedudukan guru sebagai tenaga profesional diatur dalam UUGD diantaranya yaitu untuk melaksanakan sistem pendidikan nasional, serta untuk mewujudkan tujuan pendidikan nasional, yaitu berkembangnya potensi peserta didik agar menjadi manusia yang beriman dan bertakwa kepada Tuhan Yang Maha Esa, berakhlak mulia, sehat, berilmu, cakap, kreatif, mandiri, serta menjadi warga negara yang demokratis dan bertanggung jawab.

Adapun syarat-syarat yang harus dipenuhi untuk menjadi guru profesional berdasarkan UUGD diantaranya yaitu memiliki ijasah S1, memiliki berbagai kompetensi, memiliki sertifikat 
pendidik, sehat jasmani dan rohani, serta memiliki peluang dan kemampuan untuk mewujudkan tujuan pendidikan nasional.

Seorang guru yang profesional harus memenuhi persyaratan kualifikasi akademik. Dalam UUGD, untuk menjadi seorang guru setidak-tidaknya harus menempuh pendidikan tinggi minimal S1 atau D-IV. Namun yang perlu digaris bawahi dalam hal ini adalah tidak disebutkan program sarjana atau program diploma empat kependidikan. Artinya yang berasal dari nonkependidikan pun dapat menjadi seorang guru. Dengan demikian, ketentuan ini mengisyaratkan bahwa profesi guru merupakan profesi yang terbuka. Hal ini berarti bahwa setiap orang baik dari lulusan kependidikan maupun nonkependidikan pun dapat menjadi seorang guru.

Guru yang profesional juga harus memenuhi persyaratan memiliki kompetensi tertentu sebagaimana diatur dalam UUGD diantaranya yaitu 1) kompetensi pedagogik, 2) kompetensi kepribadian, 3) kompetensi sosial, dan 4) kompetensi profesional. Kompetensi merupakan hal penting yang harus dimiliki oleh seorang guru. Untuk memiliki kompetensi tersebut, guru harus mengikuti pendidikan profesi terlebih dahulu. Melalui pendidikan profesi guru juga dapat memperoleh sertifikat pendidik.

Secara umum kebijakan sertifikasi guru diatur dalam UUGD bahwa guru yang memenuhi sejumlah persyaratan sebagaimana ditentukan oleh peraturan perundang-undangan, akan diberikan sertifikat pendidik. Proses sertifikasi guru sebagai pendidik profesional diselenggarakan oleh perguruan tinggi LPTK yang telah memenuhi persyaratan terakreditasi dan ditetapkan oleh Pemerintah. Dengan demikian perguruan tinggi LPTK memiliki kewenangan untuk menyelenggarakan program sertifikasi dan mengeluarkan sertifikat pendidik bagi seorang guru.

Ketentuan UUGD menyebutkan bahwa guru yang telah memiliki sertifikat pendidik berhak untuk diangkat pada satuan pendidikan tententu sebagai guru yang profesional. Dengan demikian, sudah semestinya pemerintah hanya boleh mengangkat guru dalam satuan pendidikan tertentu. Apabila hal ini dilakukan diluar ketentuan tersebut, pada dasarnya tindakan pemerintah sudah menyalahi aturan undang-undang guru dan dosen.

Penyelenggaraan pendidikan profesi guru sebelum berlakunya Undang-Undang Guru dan Dosen cenderung menggunakan model konkuren (concurrent). Adapun lembaga yang memiliki peran untuk menghasilkan guru pada jenjang pendidikan tinggi ketika itu adalah Lembaga Pendidikan Tenaga Kependidikan (LPTK). Bentuk penyelenggaraan pendidikan guru pada lembaga ini berupa pendidikan akademik dan juga pendidikan profesi. Dengan demikian, penyelenggaraan pendidikan guru ketika itu menggunakan model konkuren (concurrent), model ini mengintegrasikan penguasaan bidang ilmu dan penguasaan kompetensi pedagogis.

Seiring perkembangan zaman, kebijakan pendidikan profesi guru di Indonesia diatur dalam Undang-Undang Republik Indonesia Nomor 14 Tahun 2005 tentang Guru dan Dosen atau UUGD. Setelah berlakunya UUGD ini, model penyelenggaraan guru di Indonesia cenderung menggunakan model konsekutif. Akan tetapi disisi lain juga masih mempertahankan model konkuren (concurrent) yang diselenggarakan pada perguruan tinggi LPTK. Hal tersebut dapat dicermati dari beberapa ketentuan yang terdapat dalam Undang-Undang Republik Indonesia Nomor 14 Tahun 2005 tentang Guru dan Dosen atau UUGD.

\section{KESIMPULAN DAN SARAN}

Beberapa kesimpulan yang berkaitan dengan permasalahan yang dikaji, diantaranya yaitu secara tersirat dalam UUGD menyebutkan bahwa profesi guru merupakan profesi yang terbuka. Artinya, setiap orang baik lulusan LPTK ataupun non-LPTK dapat menjadi guru asalkan memenuhi persyaratan yang telah diamanatkan oleh UUGD. Ketentuan UUGD ini tentunya merupakan bentuk diskriminatif terhadap profesi guru. Selain itu, dalam implementasinya terjadi pelanggaran-pelanggaran terhadap ketentuan UUGD yang dilakukan 
oleh pemerintah. Kondisi tersebut merupakan bentuk inkonsistensi dari pemerintah dan pada dasarnya pemerintah telah melanggar ketentuan UUGD.

UUGD mengisyaratkan bahwa model penyelenggaraan pendidikan profesi guru di Indonesia cenderung bersifat konsekutif (consecutive). Akan tetapi, disisi lain model pendidikan profesi guru bersifat konkuren (concurrent) juga masih dipertahankan oleh perguruan tinggi LPTK. Hal ini tentunya menjadi sebuah ironi bagi para lulusan LPTK yang memang sejak awal dibentuk untuk menjadi calon-calon guru yang profesional. Dengan demikian, jika profesi guru diberikan kepada yang bukan ahlinya, maka akan mendatangkan kehancuran bagi profesi guru.

Berdasarkan hasil pembahasan dan analisis serta kesimpulan yang telah dibahas sebelumnya, penulis memberikan beberapa saran yakni sudah saatnya pemerintah meninjau ulang atau merevisi Undang Republik Indonesia Nomor 14 Tahun 2005 tentang Guru dan Dosen sebagai dasar kebijakan dalam profesi guru di Indonesia. Selain itu, penyelenggaraan pendidikan profesi guru sudah seharusnya dilakukan secara terintegrasi dengan pendidikan akademik (model konkuren) sebagai bentuk perlindungan profesi guru dan perlindungan terhadap eksistensi LPTK.

\section{Daftar Pustaka \\ Buku}

Jimly Asshiddiqie, Pengantar Ilmu Hukum Tata Negara Jilid I, Sekretariat Jenderal dan Kepaniteraan MK RI, Jakarta, 2006.

Nur Yanto, Pengantar Hukum Tata Negara Indonesia, Mitra Wacana Media, Jakarta, 2017.

Yuswalina dan Kun Budianto, Hukum Tata Negara Indonesia, Setara Press, Malang, 2016.

\section{Peraturan Perundang-Undangan}

Undang-Undang Dasar Negara Republik Indonesia Tahun 1945.

Undang-Undang Republik Indonesia Nomor 20 Tahun 2003 tentang Sistem Pendidikan Nasional.

Undang-Undang Republik Indonesia Nomor 14 Tahun 2005 tentang Guru dan Dosen.

Undang-Undang Republik Indonesia Nomor 12 Tahun 2012 tentang Pendidikan Tinggi.

Undang-Undang Republik Indonesia Nomor 23 Tahun 2014 Tentang Pemerintahan Daerah.

Peraturan Pemerintah Republik Indonesia Nomor 13 Tahun 2015 tentang Perubahan Kedua Atas Peraturan Pemerintah Nomor 19 Tahun 2005 tentang Standar Nasional Pendidikan.

\section{Artikel dan Jurnal}

Cecep Darmawan, “Kontroversi Profesi Guru”, Harian Umum Pikiran Rakyat, PR, Bandung, 2018.

Faridah Alawiyah, "Problematika Tata Kelola Guru dalam Implementasi Undang-Undang Guru dan Dosen”. Aspirasi: Jurnal Masalah-Masalah Sosial, Bidang Kesejahteraan Sosial Pusat Penelitian Badan Keahlian DPR RI, Jakarta, 2018.

Subijanto, "Profesi Guru sebagai Profesi yang Menjanjikan Pasca Undang-Undang Guru dan Dosen”, Jurnal Pendidikan dan Kebudayaan, Balitbang Kemendikbud, Jakarta, 2007. 